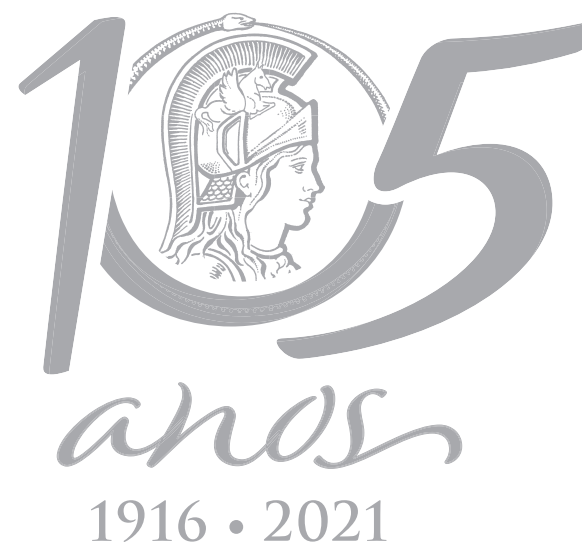

\title{
ECOSYSTEMS
}

\section{Diet of arthropodophagous bats (Mammalia, Chiroptera) from Northwestern Argentina}

\author{
SANTIAGO GAMBOA ALURRALDE \& MÓNICA DÍAZ
}

\begin{abstract}
The diet of arthropodophagous bats can be influenced by several factors. Furthermore, its study is critical for understanding their role in the ecosystem as regulators of arthropod abundance. The aim of this study was to analyze the diet of 12 species beloging to two families of arthropodophagous bats from the Yungas Forests, Northwestern Argentina. We also evaluated differences in diet between well-preserved and disturbed sites, sexes, and seasons. The specimens were collected with mist nets in eight different localities, four well-preserved and four disturbed sites of the Yungas Forests. Through the analysis of feces, arthropod remains were identified until the lowest possible taxonomic level. Volume and frequency of occurrence percentages for each food item and the niche breadth for the species were estimated. A total of 475 samples from 12 species were analyzed and their diet contained arthropods from eight orders and seven families; the highest number of consumed arthropod orders were registered for Eptesicus diminutus. A low niche breadth was recorded in general for all species. The diet was significantly influenced by season and site characteristics only in E. diminutus and E. furinalis, respectively. This showed that bats could modify its diet according to the different habitats and seasons.
\end{abstract}

Key words: feeding habits, Molossidae, Vespertilionidae, Yungas Forests.

\section{INTRODUCTION}

The structure of an assemblage is affected by several ecological parameters, being the diet one of the most important (Vitt \& Zani 1998). Food is a key dimension of the niche (Krebs 1999), and the studies about feeding habits are crucial in our understanding of the ecological relationships between species and their habitat (Belver \& Avila 2002). Additionally, this basic information can be useful in the evaluation of the conservation status of some poorly known species (Reca et al. 1994). Species at the highest trophic levels are more affected by the human activities, as well as specialist species with narrow trophic niches (Bunnel 1978, Reca et al. 1994).
At present, there are more than 1,400 recognized species of bats worldwide (Fenton \& Simmons 2014), and about $75 \%$ of them feed on arthropods (Hutson et al. 2001). Arthropodophagous bats are voracious predators of nocturnal arthropods, including many crop and forest pests, providing substantial ecosystem services (Boyles et al. 2011). The food habits of these bats can be influenced by several factors, including the time of emergence (Lee \& McCracken 2001), seasons changes and nutrient demands (Kunz et al. 1995, Lee \& McCracken 2002), temporal and spatial distribution of their prey (Whitaker et al. 1996, Henry et al. 2002), and weather conditions (Lee \& McCracken 2005). Dietary studies of arthropodophagous bats are critical for understanding their role in 
the ecosystem and as regulators of arthropod abundance (Debelica et al. 2006).

Although most species of bats are arthropodophagous (Shiel et al. 1997), in tropical environments they are usually not the dominant guild, whereas at higher latitudes its importance in the structure of bat communities increases (Gamboa Alurralde et al. 2017). In Argentina, the arthropodophagous species are dominant and represent $74 \%$ of the 67 species of bats (Barquez \& Diaz 2020, Díaz et al. 2016, Urquizo et al. 2017, Sánchez et al. 2019). Three of the five families of bats registered in the country, Emballonuridae, Molossidae, and Vespertilionidae are entirely arthropodophagous. In the other two families, Noctilionidae and Phyllostomidae, three species belong to this guild (Díaz et al. 2016).

In Argentina, the first studies of feeding habits of bats were focused on frugivorous species (Iudica 1995, Iudica \& Bonaccorso 1997, Giannini 1999, Sánchez et al. 2012a, b), whereas data on the arthropodophagous bat diet were scarce and anecdotal (Bracamonte \& Lutz 2013, N. Regueiro, unpublished data); because these bats are difficult to capture on mist nets because they avoid them (Carrol et al. 2002). However, in the last two years, new studies about arthropodopagous feeding habits were conducted. Additionaly, these were the first studies which analyzed the bat diet in relation to habitat alteration, sex, and season on molossids and vespertilionids bats in Argentina (Gamboa Alurralde \& Díaz 2018, 2019). In the present study, we describe the diet of 12 species of the families Molossidae and Vespertilionidae from the Yungas Forests in the Northwestern Argentina, and evaluate differences in diet between well-preserved and disturbed sites, sexes, and seasons. In Argentina, there is no previous information for the diet of the bat species here analyzed. An important aspect of the study of the trophic ecology of arthropodophagous bats is that the arthropods consumed often vary seasonally and in different habitats (Whitaker et al. 2009). Moreover, previous studies on diet of other arthropodophagous bat species from the same study area found differences in foraging activity in different types of land use and between seasons, but no significant differences between sexes (Gamboa Alurralde \& Díaz 2018, 2019). Therefore, we expect to observe differences in the diet of these arthropodophagous bat species among types of sites and seasons but not between males and females.

\section{MATERIALS AND METHODS}

\section{Study area}

The area belongs to the Yungas Forests ecoregion (Burkart et al. 1999), and it is represented by typical vegetation dominated by tall trees such as Cedrela lilloi (cedar), Enterolobium contortisiliquum (earpod tree), and Cinnamomum porphyrium (laurel). There are also smaller trees that do not exceed $20 \mathrm{~m}$ as Allophyllus edulis (chalchal), Celtis boliviensis (tala), among others. Bushes as Urera baccifera, Piper tucumanum and Solanum sp. are present, as well as herbs which range from smaller forms to taller than two meters (Cabrera 1976); epiphytes are abundant, and lichens, ferns, bromeliads, and mosses are dominant (Brown et al. 2001). The climate in the area is warm and humid; the annual precipitation varies between 900 and $1000 \mathrm{~mm}$, with a wet season from October to March and the rainfalls are concentrated mainly in summer (Burkart et al. 1999).

\section{Sampling}

The specimens were collected in eight different localities (Figure 1), four well-preserved and four disturbed sites of the Yungas Forests (see Appendix I), during 10 field surveys of three 


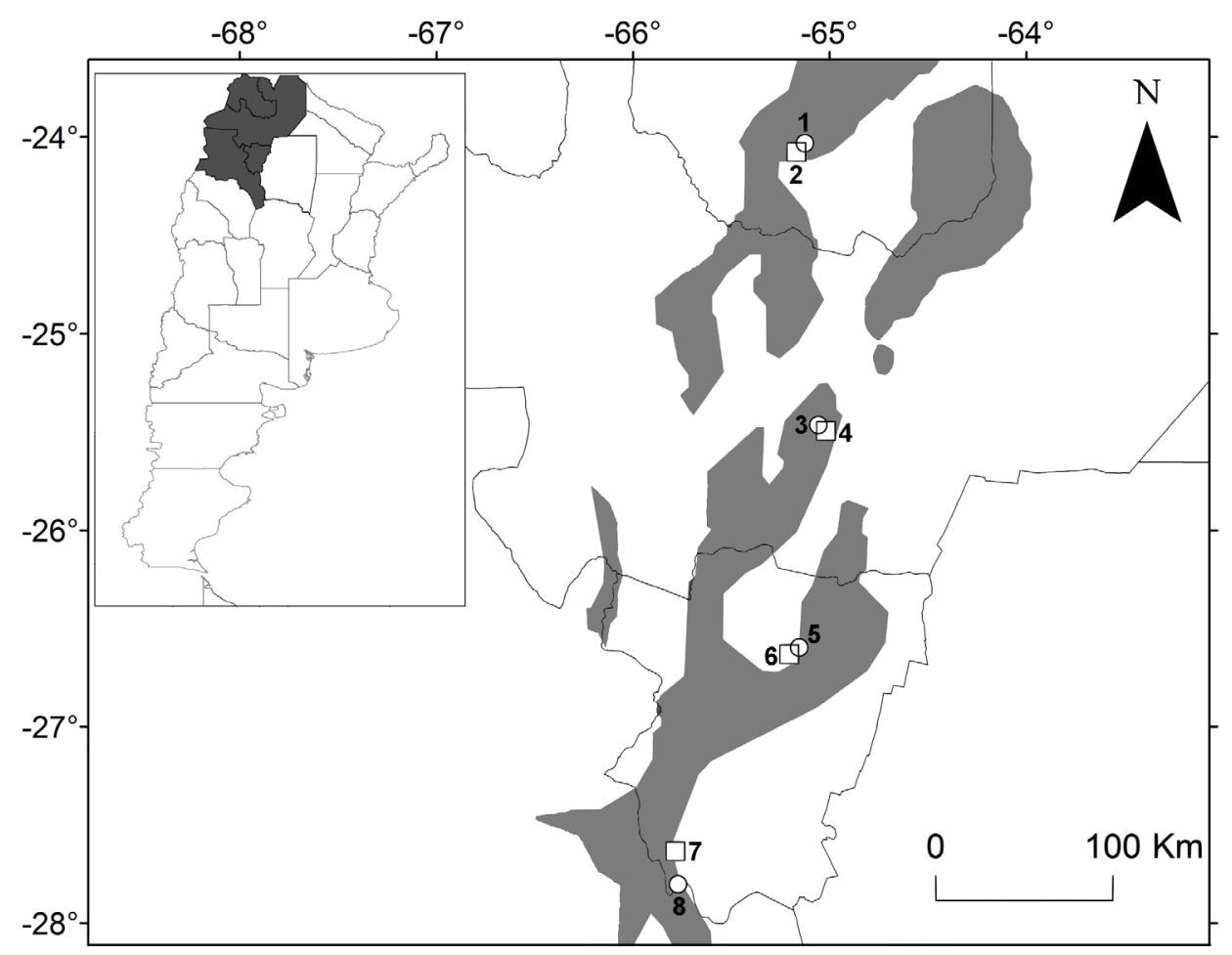

Figure 1. Collection localities in the Yungas Forests ecoregion (gray region), Northwestern Argentina. These included four wellpreserved sites (white dots) and four disturbed sites (white squares). Localities: 1. Las Capillas (Jujuy); 2. Finca Las Capillas (Jujuy); 3. Río Las Conchas (Salta); 4. Metán (Salta); 5. Reserva Aguas Chiquitas (Tucumán); 6. El Cadillal (Tucumán); 7. Villa de Batiruana (Tucumán); 8. Villa de Escaba (Catamarca). For details see Appendix I.

nights each, between September 2012 and October 2015. The sites were selected from pairs at different latitudes, and the separation distance between each pair ranged from three to $18 \mathrm{~km}$. In well-preserved sites, the vegetation was typical of the montane forest district, where all vegetation strata were recorded; whereas in disturbed sites the structure of the vegetation was modified and some strata were missing, usually bushes and small trees. In the study sites, deforestation for cattle raising and selective cutting are the main causes of habitat alteration. Additionally, we used ArcGIS 10.1 (ESRI 2011) to calculate the proportion of native forest in the landscape as a measure of forest loss (Rodríguez-San Pedro \& Simonetti 2015). Forest amount ranged from 98 to $100 \%$ in wellpreserved sites and from 79 to $88 \%$ in disturbed sites. The source of data used in the GIS analysis was the Instituto Geográfico Nacional of Argentina. The bats were captured using six 12-m mist nets, set after sunset inside the forest and over streams or rivers, and kept open for periods of six hours. External measurements, age, sex, and reproductive condition were recorded from all captured specimens following Díaz et al. (1998). To collect the fecal samples, each bat was placed in a separate, clean, cotton cloth bag for at least three hours (Lee \& McCracken 2005). The collection of specimens was authorized through permits (No. 213-13) issued by the Dirección de Flora, Fauna y Suelos, Tucuman Province. All animals were handled consistent with the animal care and use guidelines of the American Society of Mammalogists (Sikes et al. 2016).

\section{Dietary analysis}

From each specimen, up to 10 of the largest, intact, fecal pellets were examined; according to Whitaker et al. (1996) five pellets are sufficient to give reliable estimate of the diet of one individual. Each pellet, considered a sample, was soaked and softened in a Petri dish with $70 \%$ ethyl alcohol and then examined with a dissecting microscope (Lee \& McCracken 2005). Arthropod remains were sorted and identified 
to the lowest possible taxonomic level (usually family) following Whitaker (1988), Shiel et al. (1997), and Whitaker et al. (2009). Average percentage volume and percent frequency of occurrence of each food item were estimated (Whitaker et al. 2009). The percent volume is the average percentage by volume of each food type in the total sample of an individual and provides an index of the proportional contribution of arthropod taxa to the diet of bats sampled. The percent frequency of occurrence is the percentage of bats eating each food type and provides a standardized measure of the most common food type in the diet of bat species (McAney et al. 1991, Lee \& McCracken 2005).

\section{Statistical analysis}

The Levins' measure of niche breadth, $B=1 / \Sigma p_{i}^{2}$ , and its standardized version $B_{a}=B-1 / B-n$, were also estimated to assess dietary heterogeneity (Krebs 1999, Lee \& McCracken 2005), where pi is the proportion of individuals consuming a particular prey item $i$ and $n$ is the number of possible resource states. $B$ is maximal when the species does not discriminate among resources and has the broadest possible niche. Levins' $B$ is minimal when all the individuals occur in only one resource state, showing maximum specialization. The range of $B$ is from 1 to $n$, whereas $B a$ is expressed on a scale from 0 to 1 (Krebs 1999).

The differences in the diet were evaluated separately for each bat species. The species with less than three captured individuals were excluded of these analysis. For each of the other species, differences between sites, sexes, and seasons, were separately evaluated. To test for significant differences in diet composition, we performed for each factor a Nonparametric Multivariate Analysis of Variance (NPMANOVA - Anderson 2001). We determined the average volume of consumed prey for each arthropod taxa as the response variable, and the disturbance level of capture site (wellpreserved/disturbed), sex of bats (male/ female), and season (wet/dry) as explanatory variables. For each run we used the BrayCurtis similarity index for 10,000 permutations. The analyses were conducted using the free software PAST 3.11 (Hammer et al. 2001). When significant differences were observed in diet of the species, we performed General Linear Models (Crawley 2007) to determine which arthropod taxa contribute to the differences among the variables. To ensure that bat diet was not spatially autocorrelated across the sites, we used Moran's I test for species captured in more than two sites. According to this test, bat diet was not significantly autocorrelated for any of the species (Moran's I from -0.64 to -0.002, p > 0.05). These analyses were conducted using the free software R (R Core Team 2013).

\section{RESULTS}

We analyzed 475 samples from 81 specimens, belonging to 12 species of arthropodophagous bats in the Yungas Forests from Northwestern Argentina. Their diet contained arthropods from eight orders, four suborders, seven families, and one undetermined taxon (see Tables I and II). Regarding molossids bats, we registered 21 individuals from four species: Eumops bonariensis, Eumops glaucinus, Molossus molossus, and Promops nasutus (Table I). Among them, E. bonariensis (Figure 2) showed a higher number of consumed prey orders, being Coleoptera which contributed the highest volume proportion in its diet, with a total fecal volume of $49 \%$. This order was also the most commonly consumed, observed in $100 \%$ of total analyzed individuals (Table I). The other species of Eumops, E. glaucinus showed a diet dominated 
Table I. Orders, suborders and/or families of arthropods found in the diet of species of Molossidae from Northwestern Argentina. In brackets is indicated the number of individuals analyzed for each species. Average percent volume and frequency of occurrence of each item are indicated, as well as the Levins' measure of niche breadth and its standardized version.

\begin{tabular}{|c|c|c|c|c|c|c|c|c|c|}
\hline \multirow[b]{2}{*}{ Order } & \multirow[b]{2}{*}{ Subo/Family } & \multicolumn{2}{|c|}{$\begin{array}{c}\text { Eumops } \\
\text { bonariensis (7) }\end{array}$} & \multicolumn{2}{|c|}{$\begin{array}{c}\text { Eumops } \\
\text { glaucinus (9) }\end{array}$} & \multicolumn{2}{|c|}{$\begin{array}{l}\text { Molossus } \\
\text { molossus (4) }\end{array}$} & \multicolumn{2}{|c|}{$\begin{array}{c}\text { Promops nasutus } \\
\text { (1) }\end{array}$} \\
\hline & & Vol (\%) & $\begin{array}{c}\text { Freq } \\
(\%)\end{array}$ & Vol (\%) & $\begin{array}{c}\text { Freq } \\
(\%)\end{array}$ & Vol (\%) & $\begin{array}{c}\text { Freq } \\
(\%)\end{array}$ & Vol (\%) & $\begin{array}{c}\text { Freq } \\
(\%)\end{array}$ \\
\hline Araneae & Undetermined & - & - & - & - & - & - & - & - \\
\hline \multirow[t]{6}{*}{ Coleoptera } & Carabidae & 47.14 & 85.71 & - & - & - & - & - & - \\
\hline & Chrysomelidae & - & - & 5.56 & 11.11 & 0.75 & 25 & - & - \\
\hline & Curculionidae & - & - & - & - & - & - & - & - \\
\hline & Scarabeidae & 2.15 & 42.86 & 11.44 & 44.44 & 20.37 & 100 & - & - \\
\hline & Undetermined & - & - & 0.25 & 11.11 & - & - & - & - \\
\hline & $\begin{array}{c}\text { Total } \\
\text { Coleoptera }\end{array}$ & 49.29 & 100 & 17.25 & 55.55 & 21.12 & 100 & - & - \\
\hline \multirow[t]{4}{*}{ Diptera } & Brachycera & - & - & - & - & - & - & - & - \\
\hline & Nematocera & - & - & 0.17 & 11.11 & - & - & - & - \\
\hline & Culicidae & 0.28 & 14.29 & - & - & - & - & - & - \\
\hline & Total Diptera & 0.28 & 14.29 & 0.17 & 11.11 & - & - & - & - \\
\hline Hemiptera & Undetermined & 16.71 & 85.71 & 2.61 & 44.44 & 20.5 & 50 & - & - \\
\hline \multirow[t]{4}{*}{ Homoptera } & Cicadomorpha & - & - & - & - & - & - & - & - \\
\hline & Fulgoromorpha & 1.29 & 28.57 & - & - & - & - & - & - \\
\hline & Delphacidae & - & - & 0.11 & 11.11 & - & - & - & - \\
\hline & $\begin{array}{c}\text { Total } \\
\text { Homoptera }\end{array}$ & 1.29 & 28.57 & 0.11 & 11.11 & - & - & - & - \\
\hline Hymenoptera & Formicidae & - & - & - & - & 58.13 & 100 & - & - \\
\hline Lepidoptera & Undetermined & 30.29 & 85.71 & 79.86 & 100 & - & - & 100 & 100 \\
\hline Neuroptera & Crisopidae & 2.14 & 14.29 & - & - & - & - & - & - \\
\hline Undetermined & Undetermined & - & - & - & - & 0.25 & 25 & - & - \\
\hline Levins' Index & $B$ & \multicolumn{2}{|c|}{2.75} & \multicolumn{2}{|c|}{1.5} & \multicolumn{2}{|c|}{2.35} & \multicolumn{2}{|c|}{1} \\
\hline $\begin{array}{l}\text { Std Levins' } \\
\text { Index }\end{array}$ & $\mathrm{Ba}$ & \multicolumn{2}{|c|}{0.219} & \multicolumn{2}{|c|}{0.062} & \multicolumn{2}{|c|}{0.169} & \multicolumn{2}{|c|}{0} \\
\hline
\end{tabular}


by Lepidoptera. These insects represented $80 \%$ of the total volume and they were registered in all of the evaluated individuals. Regarding M. molossus, Hymenoptera contributed to the highest volume proportion of its diet, with a total fecal volume of $58 \%$; this order was registered in $100 \%$ of the analyzed individuals (Table I). In one individual of $M$. molossus arthropods of the subclass Acari were observed, however they were not taken in account for the analysis because its consumption was considered related to grooming habit. Finally, we captured only one individual of P. nasutus (Figure 2) and its diet only contained insects of the order Lepidoptera.

With respect to vespertilionids bats, we analyzed 60 individuals from eight species (Table II). The species of Eptesicus, E. diminutus and E. furinalis (Figure 2), showed the highest number of consumed prey orders. In E. diminutus, Hymenoptera contributed to the highest volume proportion of its diet, with a total fecal volume of $23 \%$. However, the most commonly consumed order by this species was Lepidoptera, registered in $100 \%$ of the analyzed individuals (Table II). On the other hand, we observed in E. furinalis a diet dominated by Coleoptera, which represented the $58 \%$ of the total fecal volume. This was also the most commonly consumed order, registered in all of the analyzed individuals. Regarding the restant species, in all of them we observed a diet dominated by Lepidoptera, which represented $63-98 \%$ of the total volume and it was registered in $100 \%$ of individuals analized for each species (Table II). Except for Eptesicus diminutus, the analyzed species of bats showed low values of niche breadth ( $B=1.04-2.66, B a=0.005-0.207$; see Tables I and II), indicating a low diversity diet.

We evaluated the diet composition of 12 species of bats according to three different variables: site, sex, and season (see Appendix II). We only observed differences in the diet of Eptesicus diminutus and E. furinalis, between seasons and sites, respectively. For E. diminutus, the registered variations were significantly different according to the NPMANOVA ( $p=0.049$ ), being Hymenoptera the order that was mostly contributing to the dissimilarities according to the GLM ( $p<0.0001)$. Hymenopterans were mostly consumed by $E$. diminutus in dry season (Figure 3). Regarding E. furinalis, the registered variations by sites were significantly different according to the NPMANOVA ( $p=0.006)$, being Coleoptera $(p=0.002)$, Hemiptera $(p=0.023)$, and Homoptera $(p=0.018)$ the arthropod orders most contributing to the dissimilarities according to the GLM. Coleoptera was mostly

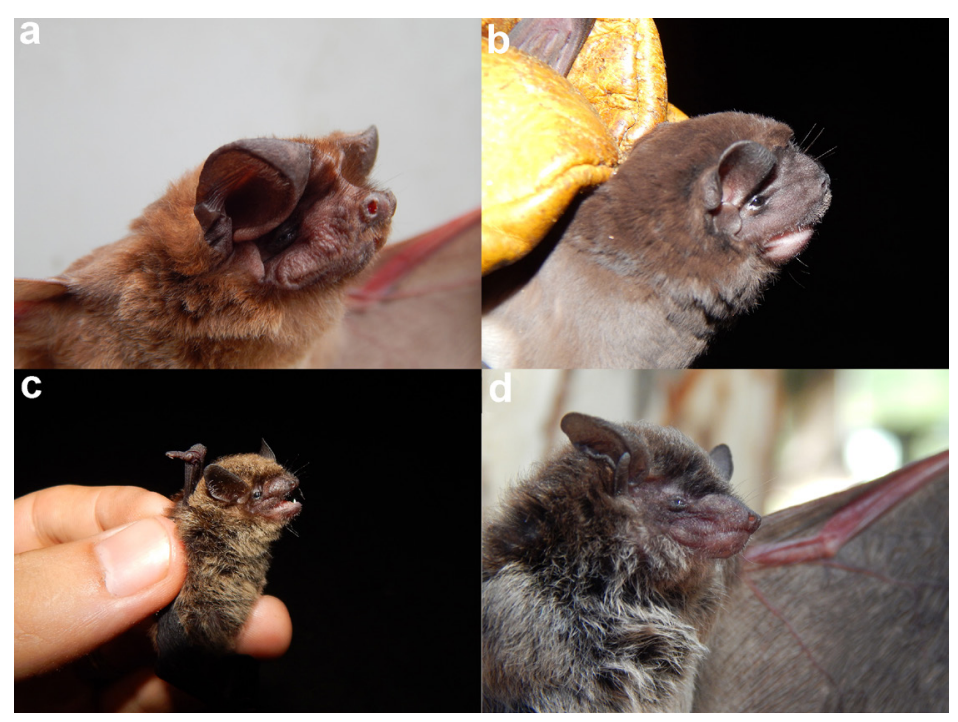

Figure 2. Adult individuals of Eumops bonariensis (a), Promops nasutus (b), Eptesicus diminutus (c) and Eptesicus furinalis (d) captured in the study area. Photos by Santiago Gamboa Alurralde. 
Table II. Orders, suborders and/or families of arthropods found in the diet of species of Vespertilionidae from Northwestern Argentina. In brackets is indicated the number of individuals analyzed for each species. Average percent volume and frequency of occurrence of each item are indicated, as well as the Levins' measure of niche breadth and its standardized version.

\begin{tabular}{|c|c|c|c|c|c|c|c|c|c|}
\hline \multirow[b]{2}{*}{ Order } & \multirow[b]{2}{*}{ Subo/Family } & \multicolumn{2}{|c|}{$\begin{array}{c}\text { Dasypterus ega } \\
\text { (3) }\end{array}$} & \multicolumn{2}{|c|}{$\begin{array}{c}\text { Eptesicus } \\
\text { diminutus (7) }\end{array}$} & \multicolumn{2}{|c|}{$\begin{array}{c}\text { Eptesicus } \\
\text { furinalis (25) }\end{array}$} & \multicolumn{2}{|c|}{$\begin{array}{c}\text { Histiotus } \\
\text { laephotis (1) }\end{array}$} \\
\hline & & $\begin{array}{l}\text { Vol } \\
(\%)\end{array}$ & $\begin{array}{l}\text { Freq } \\
(\%)\end{array}$ & $\begin{array}{l}\text { Vol } \\
\text { (\%) }\end{array}$ & $\begin{array}{l}\text { Freq } \\
(\%)\end{array}$ & $\begin{array}{l}\text { Vol } \\
\text { (\%) }\end{array}$ & $\begin{array}{l}\text { Freq } \\
(\%)\end{array}$ & $\begin{array}{l}\text { Vol } \\
\text { (\%) }\end{array}$ & $\begin{array}{l}\text { Freq } \\
(\%)\end{array}$ \\
\hline Araneae & Undetermined & - & - & 1.43 & 28.57 & 0.04 & 4 & - & - \\
\hline \multirow[t]{6}{*}{ Coleoptera } & Carabidae & 26.83 & 33.33 & 7.43 & 57.14 & 7.62 & 36 & - & - \\
\hline & Chrysomelidae & - & - & 4.57 & 42.86 & 7.26 & 48 & - & - \\
\hline & Curculionidae & - & - & - & - & 3.6 & 20 & - & - \\
\hline & Scarabeidae & 7.17 & 66.67 & 6.57 & 28.57 & 36.95 & 68 & 4 & 100 \\
\hline & Undetermined & - & - & - & - & 2.16 & 8 & - & - \\
\hline & Total Coleoptera & 34 & 66.67 & 18.57 & 71.43 & 57.63 & 100 & 4 & 100 \\
\hline \multirow[t]{4}{*}{ Diptera } & Brachycera & 1.83 & 66.67 & 0.29 & 14.29 & 0.24 & 8 & - & - \\
\hline & Nematocera & - & - & 0.43 & 14.29 & 0.4 & 20 & - & - \\
\hline & Culicidae & - & - & 3.71 & 14.29 & - & - & - & - \\
\hline & Total Diptera & 1.83 & 66.67 & 4.43 & 28.57 & 0.64 & 24 & - & - \\
\hline Hemiptera & Undetermined & - & - & 20 & 100 & 7.06 & 52 & - & - \\
\hline \multirow[t]{4}{*}{ Homoptera } & Cicadomorpha & - & - & 1.43 & 28.57 & 1.64 & 36 & - & - \\
\hline & Fulgoromorpha & - & - & 4.43 & 57.14 & 7.36 & 36 & - & - \\
\hline & Delphacidae & - & - & 5 & 28.57 & 4.48 & 16 & - & - \\
\hline & Total Homoptera & - & - & 10.86 & 57.14 & 13.48 & 44 & - & - \\
\hline Hymenoptera & Formicidae & - & - & 22.57 & 57.14 & 7.85 & 36 & - & - \\
\hline Lepidoptera & Undetermined & 62.83 & 100 & 20.43 & 100 & 12.14 & 52 & 96 & 100 \\
\hline Neuroptera & Crisopidae & 1.34 & 33.33 & 1.71 & 28.57 & 0.96 & 12 & - & - \\
\hline Undetermined & Undetermined & - & - & - & - & 0.2 & 4 & - & - \\
\hline Levins' Index & B & \multicolumn{2}{|c|}{1.96} & \multicolumn{2}{|c|}{5.51} & \multicolumn{2}{|c|}{2.66} & \multicolumn{2}{|c|}{1.08} \\
\hline $\begin{array}{l}\text { Std Levins' } \\
\text { Index }\end{array}$ & $\mathrm{Ba}$ & \multicolumn{2}{|c|}{0.12} & \multicolumn{2}{|c|}{0.564} & \multicolumn{2}{|c|}{0.207} & \multicolumn{2}{|c|}{0.01} \\
\hline
\end{tabular}


Table II. Continuation.

\begin{tabular}{|c|c|c|c|c|c|c|c|c|c|}
\hline \multirow[b]{2}{*}{ Order } & \multirow[b]{2}{*}{ Subo/Family } & \multicolumn{2}{|c|}{$\begin{array}{c}\text { Histiotus } \\
\text { macrotus (6) }\end{array}$} & \multicolumn{2}{|c|}{$\begin{array}{c}\text { Histiotus } \\
\text { velatus (1) }\end{array}$} & \multicolumn{2}{|c|}{$\begin{array}{c}\text { Lasiurus } \\
\text { blossevillii (15) }\end{array}$} & \multicolumn{2}{|c|}{$\begin{array}{c}\text { Lasiurus } \\
\text { villosissimus (2) }\end{array}$} \\
\hline & & $\begin{array}{l}\text { Vol } \\
(\%)\end{array}$ & $\begin{array}{c}\text { Freq } \\
(\%)\end{array}$ & $\begin{array}{l}\text { Vol } \\
(\%)\end{array}$ & $\begin{array}{c}\text { Freq } \\
(\%)\end{array}$ & $\begin{array}{l}\text { Vol } \\
(\%)\end{array}$ & $\begin{array}{l}\text { Freq } \\
(\%)\end{array}$ & $\begin{array}{l}\text { Vol } \\
(\%)\end{array}$ & $\begin{array}{c}\text { Freq } \\
(\%)\end{array}$ \\
\hline Araneae & Undetermined & - & - & - & - & - & - & - & - \\
\hline \multirow[t]{6}{*}{ Coleoptera } & Carabidae & - & - & - & - & - & - & - & - \\
\hline & Chrysomelidae & 2.67 & 33.33 & - & - & - & - & - & - \\
\hline & Curculionidae & - & - & - & - & - & - & - & - \\
\hline & Scarabeidae & - & - & 16 & 100 & - & - & - & - \\
\hline & Undetermined & - & - & - & - & - & - & - & - \\
\hline & Total Coleoptera & 2.67 & 33.33 & 16 & 100 & - & - & - & - \\
\hline \multirow[t]{4}{*}{ Diptera } & Brachycera & - & - & - & - & - & - & - & - \\
\hline & Nematocera & 1.19 & 16.67 & - & - & - & - & - & - \\
\hline & Culicidae & - & - & - & - & - & - & - & - \\
\hline & Total Diptera & 1.19 & 16.67 & - & - & - & - & - & - \\
\hline Hemiptera & Undetermined & 0.95 & 16.67 & - & - & - & - & 0.5 & 50 \\
\hline \multirow[t]{4}{*}{ Homoptera } & Cicadomorpha & - & - & - & - & - & - & - & - \\
\hline & Fulgoromorpha & - & - & - & - & 0.2 & 6.67 & 7 & 50 \\
\hline & Delphacidae & - & - & - & - & - & - & - & - \\
\hline & Total Homoptera & - & - & - & - & 0.2 & 6.67 & 7 & 50 \\
\hline Hymenoptera & Formicidae & - & - & - & - & - & - & - & - \\
\hline Lepidoptera & Undetermined & 95.19 & 100 & 84 & 100 & 98 & 100 & 92.5 & 100 \\
\hline Neuroptera & Crisopidae & - & - & - & - & 1.8 & 40 & - & - \\
\hline Undetermined & Undetermined & - & - & - & - & - & - & - & - \\
\hline Levins' Index & $B$ & \multicolumn{2}{|c|}{1.1} & \multicolumn{2}{|c|}{1.37} & \multicolumn{2}{|c|}{1.04} & \multicolumn{2}{|c|}{1.16} \\
\hline $\begin{array}{l}\text { Std Levins' } \\
\text { Index }\end{array}$ & $\mathrm{Ba}$ & \multicolumn{2}{|c|}{0.012} & \multicolumn{2}{|c|}{0.046} & \multicolumn{2}{|c|}{0.005} & \multicolumn{2}{|c|}{0.02} \\
\hline
\end{tabular}

consumed by E. furinalis in disturbed sites, whereas Hemiptera and Homoptera were mainly consumed in well-preserved ones (Figure 4). For this species, the observed variations between sexes were not significantly different according to the NPMANOVA $(p=0.736)$

\section{DISCUSSION}

This study analyzed the diet of arthropodophagous bats from the families Molossidae and Vespertilionidae in Argentina, adding important information in the southward part of the distribution of these species. Except for Eptesicus diminutus, we registered for all species a low diversity diet. This was reflected 


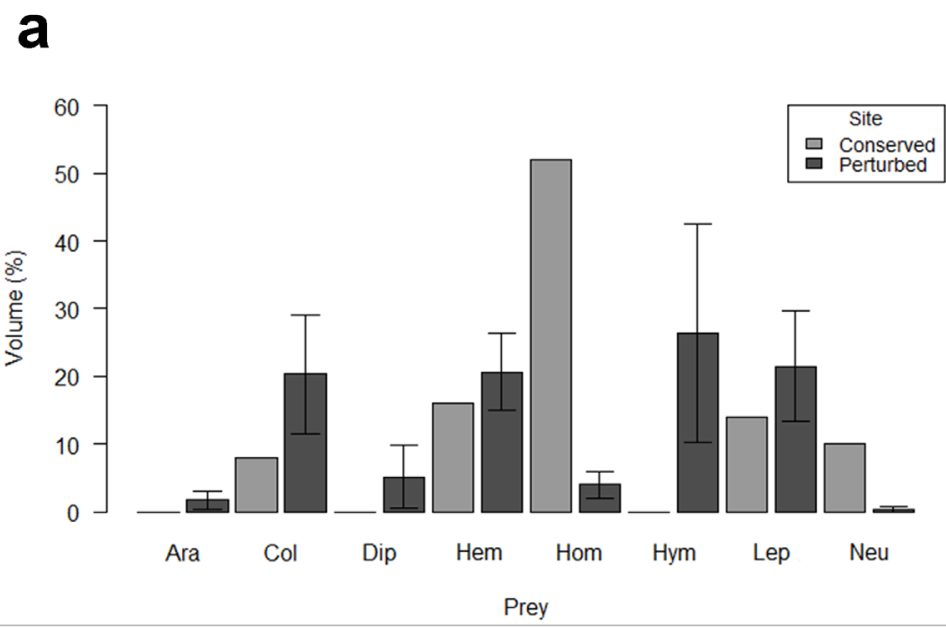

Figure 3. Percent volume and Standard Error of each prey order identified in the diet of Eptesicus diminutus compared between sites (a), and seasons (b). The arthropod orders that showed significant differences between treatments are marked with *. Abbreviations for arthropod orders: Ara, Araneae; Col, Coleoptera; Dip, Diptera; Hem, Hemiptera; Hom, Homoptera; Hym, Hymenoptera; Lep, Lepidoptera; and Neu, Neuroptera.

\section{b}

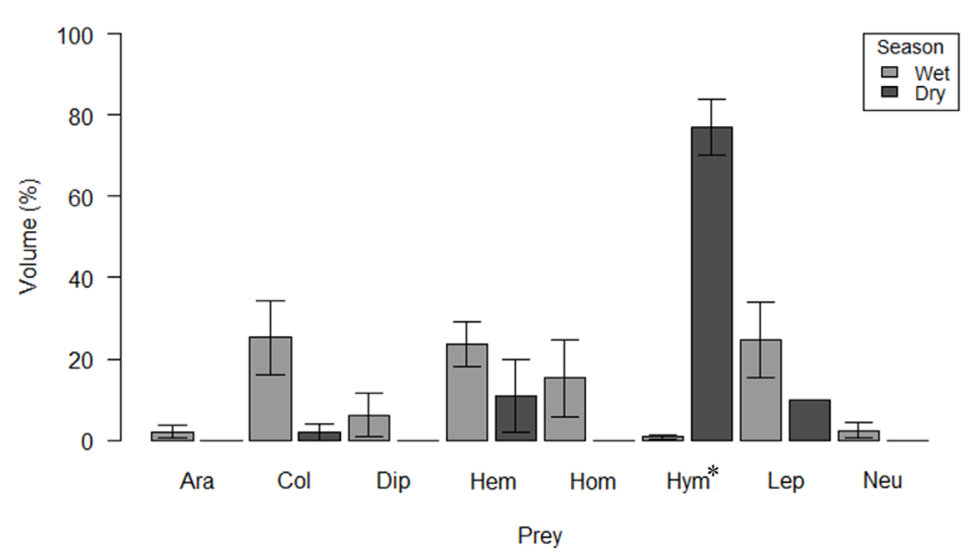

in the niche breadth, according to the values of both measures. The low diversity was a result, in general, of the elevated consumption of moths by the different species. These results were similar to those obtained in another study conducted on diet of four species of Myotis (Vespertilionidae) in the same study area (see Gamboa Alurralde \& Díaz 2019), where low values of both niche breadth measures were registered ( $B=1.43-2.93, B a=0.05-0.24)$. Eptesicus diminutus was the exception to this general pattern with a diet that included eight orders and seven families of arthropods. These heterogeneity was also reflected in the Levins' measures of niche breadth. These values were higher than obtained for another arthropodophagous bat in the same study area, Tadarida brasiliensis $(B=$
4.17, $B a=0.40)$, which is known to have a great diverse diet (Gamboa Alurralde \& Díaz 2018).

Regarding the molossids species here analyzed, little is known of its biology in Argentina (Barquez et al. 1999). The diet of Eumops bonariensis was described by Bowles et al. (1990) in Mexico, however posterior studies showed that the species studied by these authors corresponds to E. delticus (Eger 2008). Thus, the information here reported for E. bonariensis (see Table I) represented unpublished data. For E. glaucinus, several arthropod orders had been registered in its diet (Belwood 1981, Best et al. 1997, Aguirre et al. 2003). In this study, we registered similar results and added the order Homoptera to the diet of this species. A great number of arthropod orders had been 


\section{a}

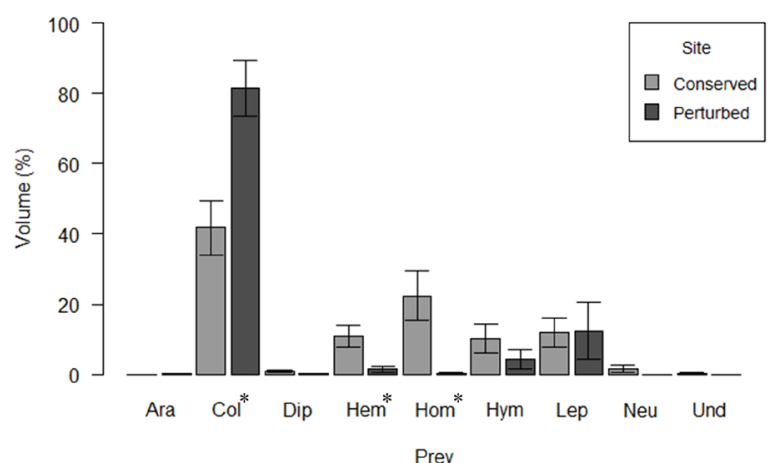

\section{b}
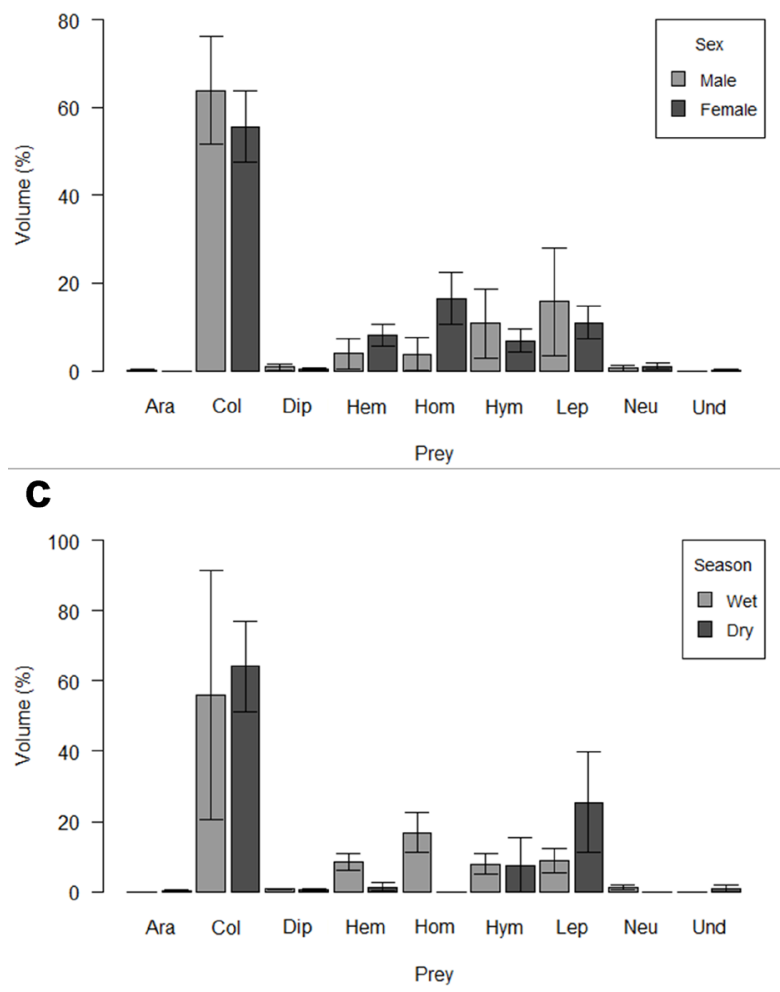

Figure 4. Percent volume and Standard Error of each prey order identified in the diet of Eptesicus furinalis compared between sites (a), sexes (b), and seasons (c). The arthropod orders that showed significant differences between treatments are marked with *. Abbreviations for arthropod orders: Ara, Araneae; Col, Coleoptera; Dip, Diptera; Hem, Hemiptera; Hom, Homoptera; Hym, Hymenoptera; Lep, Lepidoptera; Neu, Neuroptera; and Und, Undetermined. registered in the diet of Molossus molossus (Willig et al. 1993, Ramírez-Chaves et al. 2008, A. Rodales, unpublished data), and our results were consistent with these studies. In addition, we observed in this species many individuals of the subclass Acari, but they were considered as ingested during self-grooming (see Gamboa Alurralde \& Díaz 2019, L. Damián, unpublished data). With regards to the diet of Promops nasutus, no data were found in previous researches, thus the results here obtained are inedit for the species.

In vespertilionids species, a few arthropod orders had been registered in the diet of Dasypterus ega (Ross 1967, Kurta \& Lehr 1995); here we added the orders Diptera and Neuroptera. The biology, in general, and the diet in particular are almost unknown for Eptesicus diminutus (Barquez et al. 1999, Davis \& Gardner 2008). Except for Coleoptera, all arthropod orders registered in this study represented inedit data for this species. For the other species of Eptesicus analyzed, E. furinalis, several arthropod orders had been registered in its diet (Aguiar \& Antonini 2008, Bracamonte 2013, A. Rodales, unpublished data); we added here the order Araneae. The consumption of spiders had been already registered for arthropodophagous bats (Aguirre et al. 2003, Kaupas \& Barclay 2018, Shively et al. 2018), including other species in the same study area (Gamboa Alurralde \& Díaz 2018, 2019). Shively et al. (2018) registered for Myotis lucifugus that the majority of the spiders were orbweavers (Araneidae), which supports the hypothesis that little brown bats are likely gleaning spiders from webs. We could not identify in this study the kind of spiders consumed by the species of bats, therefore the hypothesis of the extraction from the web is one possibility. Another possibility is an accidental ingestion during self-grooming on the roost (see Gamboa Alurralde \& Díaz 2019). We analyzed 
the diet of three species of Histiotus and two of Lasiurus with similar results in each genus. The diet information obtained for both genera was similar to the reported in previous studies (Rolseth et al. 1994, Fenton et al. 1999, Zanon \& dos Reis 2007, Valdez \& Cryan 2009, Giménez 2010, Bracamonte 2013, dos Reis et al. 2013). For $H$. laephotis and $H$. velatus the results are preliminary because only one individual of each species were captured.

In contrast with our expectations, when we evaluated the diet composition of the 12 species of arthropodophagous bats according to three different variables, we only registered significant differences in the diet of both species of Eptesicus. The amount of forest cover was high even in the disturbed sites, this might be responsible for the lack of betweensite differences observed. On the other hand, the lower sample size of several species may have influenced the obtained results. In $E$. diminutus, we found significant differences in the diet between seasons, with a higher consumption of Hymenoptera (Formicidae) in the dry season. It is important to mention that in Northwestern Argentina, many ant species conduct their nuptial flights at night and during the dry season (Kusnezov 1962). Similar results were obteined for Tadarida brasiliensis in the same study area (Gamboa Alurralde \& Díaz 2018). Regarding E. furinalis, we found significant differences in the diet between sites with a higher consumption of Coleoptera in disturbed sites, whereas in conserved ones it showed a higher consumption of Hemiptera and Homoptera. The former results were consistent with the great abundance of coleopterans in highly fragmented habitats (Bustamante et al. 2006, de la Vega \& Grez 2008), whereas the latter results coul be an indication of a higher abundance of hemipterans and homopterans in conserved sites, but further studies are needed to confirm this.

Coleopterans, lepidopterans, homopterans, and hemipterans are among the major pests in farms (Oliveira 2005), and we observed these orders in the diet of the 12 analyzed species. Thus, the obtained results would be consistent with their role as natural pest controllers. However, the proportion of crop pest remains in the bats diet is unclear due to the difficulty of identifying highly masticated arthropod fragments in the feces to species. DNA metabarcoding analyses to document predation by arthropodophagous species are necessary in order to confirm their role as pest controllers in Argentina.

This study provides baseline research in Argentina and adds new information about the diet of some species of arthropodophagous bats, as Eumops bonariensis and Promops nasutus. However, is difficult to identify masticated arthropod fragments in the feces to species, therefore for identifyng the lowest taxonomic levels of arthropods we recommend DNA metabarcoding analyses. But the study of bat diet is still incipient, actually we added new arthropod orders for several of the other species here analyzed. This study includes the evaluation of the effects of different variables on the diet of molossid and vespertilionid bats in Argentina. Moreover, we registered differences in the diet of two species between well-preserved and disturbed sites and between wet and dry seasons, showing that bats can modify their diet according to habitat quality and season of the year. In contrast, for the rest of the analyzed species we found no differences on bat diet in response to these variables. The high abundance of arthropods in the study area, independently of the site or season, could be the reason of these results. Further studies of bat diet that include more analyzed individuals of bats and also the arthropod composition and abundance of the study sites are necessary to test this hypothesis. 


\section{Acknowledgments}

We wish to acknowledge all the members of PIDBA for extending their support during our field collection trips. We thank Raquel Gandolfo, Álvaro Galbán, Paola Martín, Pablo Ramello, Bárbara Defea, and Ana Rodales for their help on the identification of arthropod orders. We are also grateful to the three anonymous reviewers for valuable comments that improved a previous version of the manuscript.

\section{REFERENCES}

AGUIAR LMS \& ANTONINI Y. 2008. Diet of two sympatric insectivores bats (Chiroptera: Vespertilionidae) in the Cerrado of Central Brazil. Rev Bras Zool 25: 28-31.

AGUIRRE LF, HERREL AF, VAN DAMME R \& MATTHYSEN E. 2003. The implications of food hardness for diet in bats. Func Ecol 17: 201-212.

ANDERSON MJ. 2001. A new method for non-parametric multivariate analysis of variance. Austral Ecol 26: 32-46.

BARQUEZ RM \& DÍAZ MM. 2020. Nueva guía de Murciélagos de Argentina. Publicación Especial PCMA (Programa de Conservación de los Murciélagos de Argentina), Nro 3. Tucumán, Argentina.

BARQUEZ RM, MARES MA \& BRAUN JK. 1999. The bats of Argentina. Lubbock: Museum of Texas Tech University, p. 275.

BELVER LC \& AVILA LJ. 2002. Diet composition of LiolaemuS bibronii (Iguania:Liolaemidae) in southern Rio Negro Province, Argentina. Herpetol J 12: 39-42.

BELWOOD JJ. 1981. Wagner's mastiff bat, Eumops glaucinus floridanus, (Molossidae) in southwestern Florida. J Mammal 62: 233-457.

BEST TL, KISER WM \& RAINEY J. 1997. Eumops glaucinus. Mamm Species 551: 1-6.

BOWLES JB, HEIDEMAN PD \& ERICKSON KR. 1990. Observations on six species of free-tailed bats (Molossidae) from Yucatán, Mexico. Southwest Nat 35: 151-157.

BOYLES JG, CRYAN PM, MCCRACKEN GF \& KUNZ TH. 2011. Economic importance of bats in agriculture. Science 332 : 41.

BRACAMONTE JC. 2013. Hábitos alimenticios de un ensamble de murciélagos insectivoros aéreos de un bosque montano en las Yungas Argentinas. Chiroptera Neotrop 19: 1157-1162.

BRACAMONTE JC \& LUTZ MA. 2013. Nuevos registros de Eumops dabbenei (Chiroptera: Molossidae) en Argentina: ampliación de la distribución y comentarios sobre su ecología. Mastozool Neotrop 20: 139-142.
BROWN AD, GRAU HR, MALIZIA LR \& GRAU A. 2001. Argentina. In: Kapelle M \& Brown AD (Eds), Bosques nublados del Neotrópico, San José de Costa Rica: Instituto Nacional de Biodiversidad (INBio), Costa Rica, p. 623-659.

BUNNELL FL. 1978. Constraints of small populations. In: Proceedings of a Working Meeting of the Deer Specialist Group of the Survival Services Comission, Gland: IUCN/ SSC Pulications, p. 265-287.

BURKART R, BÁRBARO NO, SÁNCHEZ RO \& GÓMEZ DA. 1999. Ecoregiones de la Argentina. Buenos Aires: Administración de Parques Nacionales, p. 43.

BUSTAMANTE RO, GREZ AA \& SIMONETTI JA. 2006. Efectos de la fragmentación del bosque maulino sobre la abundancia y diversidad de especies nativas. In: Grez AA, Simonetti JA \& Bustamante RO (Eds), Biodiversidad en ambientes fragmentados de Chile: patrones y procesos a diferentes escalas, Santiago de Chile: Editorial Universitaria, Chile, p. 83-97.

CABRERA AL. 1976. Regiones Fitogeográficas Argentinas. Buenos Aires: ACME, p. 85.

CARROL SK, CARTER TC \& FELDHAMER GA. 2002. Placement on nets for bats: effects on perceived fauna. Southeast Nat 1: 193-198.

CRAWLEY MJ. 2007. The R book. West Sussex: John Wiley \& Sons Ltd, p. 942.

DAVIS WB \& GARDNER AL. 2008. Genus Eptesicus. In: Gardner AL (Ed), Mammals of South America. Volume 1. Marsupials, Xenarthrans, Shrews, and Bats, Chicago: The University of Chicago Press, USA 1: 440-450.

DEBELICA A, MATTHEWS AK \& AMMERMAN LK. 2006. Dietary study of big free-tailed bats (Nyctinomops macrotis) in Big Bend National Park, Texas. Southwest Nat 51: 414-418.

DE LA VEGA X \& GREZ AA. 2008. Composición, riqueza de especies y abundancia de insectos defoliadores de actividad nocturna asociados a Aristotelia chilensis (Maqui) en el bosque maulino fragmentado. Rev Chilena Hist Nat 81: 221-238.

DÍAZ MM, FLORES DA \& BARQUEZ RM. 1998. Instrucciones para la preparación y conservación de mamíferos. San Miguel deTucumán: PIDBA Publicaciones Especiales, p. 44.

DÍAZ MM, SOLARI S, AGUIRRE LF, AGUIAR LMS \& BARQUEZ RM. 2016. Clave de identificación de los murciélagos de Sudamérica. San Miguel de Tucumán: PCMA Publicaciones Especiales, p. 160.

DOS REIS NR, NUNES FREGONEZI M, PERACCHI AL \& SHIBATTA OA. 2013. Morcegos do Brasil: guía de campo. Rio de Janeiro: Technical Books, p. 252.

EGER JL. 2008. Family Molossidae. In: Gardner AL (Ed), Mammals of South America. Volume 1. Marsupials, 
Xenarthrans, Shrews, and Bats, Chicago: The University of Chicago Press, USA 1: 399-439.

ESRI. 2011. ArgGIS Desktop: Release 10. Environmental Systems Research Institute, Redlands.

FENTON MB \& SIMMONS NB. 2014. Bats. A world of science and mystery. Chicago: University of Chicago Press, p. 240.

FENTON MB ET AL. 1999. The diet of bats from Southeastern Brazil: the relation to echolocation and foraging behaviour. Rev Bras Zool 16: 1081-1085.

GAMBOA ALURRALDE S, BARQUEZ RM \& DÍAZ MM. 2017. New records of bats (Mammalia: Chiroptera) for a southern locality of the Argentine Yungas. Check List 13: 2105.

GAMBOA ALURRALDE S \& DÍAZ MM. 2018. Diet of Tadarida brasiliensis (Mammalia: Chiroptera) in Northwestern Argentina. Acta Chiropterol 20: 221-228.

GAMBOA ALURRALDE S \& DÍAZ MM. 2019. Feeding habits of four species of Myotis (Mammalia, Chiroptera) from Argentina. Mamm Res https://doi.org/10.1007/ s13364-019-00431-8.

GIANNINI NP. 1999. Selection of diet and elevation of two sympatric species of Sturnira in an Andean rainforest. J Mammal 80: 1186-1195.

GIMÉNEZ AL. 2010. Primeros registros de Histiotus macrotus (Chiroptera: Vespertilionidae) en la provincia del Chubut, Argentina. Mastozool Neotrop 17: 375-380.

HAMMER $\varnothing$, HARPER DAT \& RYAN PD. 2001. PAST: Paleontological Statistics Software Package for Education and Data Analysis. Palaeontol Electron 4: 9.

HENRY M, THOMAS DW, VAUDRY R \& CARRIER M. 2002. Foraging distances and home range of pregnant and lactating little brown bats (Myotis lucifugus). J Mammal 83: 767-774.

HUTSON AM, MICKLEBURGH SP \& RACEY PA. 2001. Microchiropteran bats: globlal status survey and conservation action plan. Cambridge: IUCN/SSC Chiroptera Specialist Group, p. 258.

IUDICA CA. 1995. Frugivoría en murciélagos: el frutero común (Sturnira lilium) en las Yungas de Jujuy, Argentina. In: Brown AD \& Grau HR (Eds), Investigación, conservación y desarrollo de las selvas subtropicales de montaña, San Miguel de Tucumán: Laboratorio de Investigaciones Ecológicas de las Yungas, Argentina, p. 123-128.

IUDICA CA \& BONACCORSO FJ. 1997. Feeding of the bat, Sturnira lilium, on fruits of Solanum riparium influences dispersal of this pioneer tree in forests of northwestern Argentina. Stud Neotrop Fauna Environ 32: 4-6.

KAUPAS LA \& BARCLAY RMR. 2018. Temperature-dependent consumption of spiders by little brown bats (Myotis lucifugus), but not northern long-eared bats ( $M$. septentrionalis), in northern Canada. Can J Zool 96: 261-268.

KREBS CJ. 1999. Ecological Methodology. California: Benjamin Cummings, 620 p.

KUNZ TH, OFTEDAL OT, ROBSON S, KRETZMANN MB \& KIRK C. 1995. Changes in milk composition during lactation in three species of insectivorous bats. I Comp Physiol B 164: 543-551.

KURTA A \& LEHR GC. 1995. Lasiurus ega. Mamm Species 515: 1-7.

KUSNEZOV N. 1962. El vuelo nupcial de las hormigas. Acta Zool Lilloana 18: 385-442.

LEE Y \& MCCRACKEN GF. 2001. Timing and variation in the emergence and return of a large colony of Mexican freetailed bats (Tadarida brasiliensis mexicana). Zool Stud 40: 309-316.

LEE Y \& MCCRACKEN GF. 2002. Foraging activity and resource use of Brazilian free-tailed bats Tadarida brasiliensis (Molossidae). Ecoscience 9: 306-313.

LEE Y \& MCCRACKEN GF. 2005. Dietary variation of Brazilian free-tailed bats links to migratory populations of pest insects. J Mammal 86: 67-76.

MCANEY C, SHIEL C, SULLIVAN C \& FAIRLEY J. 1991. The analysis of bat droppings. London: Occasional Publication of the Mammal Society 14: 48.

OLIVEIRA CM. 2005. Aspectos bioecológicos do coró-dashortaliças Aegopsis bolboceridus (Thomson) (Coleoptera: Melolonthidae) no Cerrado do Brasil Central. Embrapa Cerrados Série Documentos 143: 1-28.

R CORE TEAM. 2013. R: A language and environment for statistical computing. R Foundation for Statistical Computing, Vienna, Austria. URL http://www.R-project. org/.

RAMÍREZ-CHAVES HE, MEJÍAS-EGAS O \& ZAMBRANO G. 2008. Anotaciones sobre dieta, estado reproductivo, actividad y tamaño de colonia de murciélago mastín común (Molossus molossus: Molossidae) en la zona urbana de Popayán, Departamento del Cauca, Colombia. Chiroptera Neotrop 14: 384-390.

RECA A, UBEDA C \& GRIGERA D. 1994. Conservación de la fauna de tetrápodos. Un índice para su evaluación. Mastozool Neotrop 1: 17-28.

RODRÍGUEZ-SAN PEDRO A \& SIMONETTI JA. 2015. The relative influence of forest loss and fragmentation on insectivorous bats: does the type of matrix matter? Landsc Ecol 30: 1561-1572.

ROLSETH SL, KOEHLER CE \& BARCLAY RMR. 1994. Differences in the diets of juvenile ahd adult hoary bats, Lasiurus cinereus. J Mammal 75: 394-398. 
ROSS A. 1967. Ecological aspects of the food habits of insectivorous bats. Proc Western Found Vertebrate Zool 1: 205-264.

SÁNCHEZ MS, CARRIZO LV, GIANNINI NP \& BARQUEZ RM. 2012a. Seasonal patterns in the diet of frugivorous bats in the subtropical rainforest of Argentina. Mammalia 76: 269-275.

SÁNCHEZ MS, GIANNINI NP \& BARQUEZ RM. 2012b. Bat frugivory in two subtropical rain forests of Northern Argentina: testing hypotheses of fruit selection in the Neotropics. Mammal Biol 77: 22-31.

SÁNCHEZ RT, MONTANI ME, TOMASCO IH, DÍAZ MM \& BARQUEZ RM. 2019. A new species of Eptesicus (Chiroptera, Vespertilionidae) from Argentina. J Mammal 100: 118-129.

SHIEL C, MCANEY C, SULLIVAN C \& FAIRLEY J. 1997. Identification of arthropod fragments in bat droppings. London: Occasional Publication of the Mammal Society 17: 57.

SHIVELY R, BARBOZA P, DOAK P \& JUNG TS. 2018. Increased diet breadth of little brown bats (Myotis lucifugus) at their norhtern range limit: a multimethod approach. Can J Zool 96: 31-38.

SIKES RS \& THE ANIMAL CARE AND USE COMMITTEE OF THE AMERICAN SOCIETY OF MAMMALOGISTS. 2016. 2016 Guidelines of the American Society of Mammalogists for the use of wild mammals in research and education. J Mammal 97: 663-688.

URQUIZO JH, DÍAZ MM \& BARQUEZ RM. 2017. Una nueva especie de Myotis (Chiroptera: Vespertilionidae) para la Argentina. Mastozool Neotrop 24: 257-261.

VALDEZ EW \& CRYAN PM. 2009. Food habits of the hoary bat (Lasiurus cinereus) during spring migration through New Mexico. Southwest Nat 54: 195-200.

VITT LJ \& ZANI PA. 1998. Ecological relationships among sympatric lizards in a transitional forest in the northern Amazon of Brazil. J Trop Ecol 14: 63-86.

WHITAKER JO JR. 1988. Food habits analysis of insectivorous bats. In: Kunz TH (Ed), Ecological and behavioral methods for the study of bats, Washington, D. C.: Smithsonian Institution Press, USA, p. 171-189.

WHITAKER JO JR, MCCRACKEN GF \& SIEMERS BM. 2009. Food habits analysis of insectivorous bats. In: Kunz TH \& Parsons S (Eds) Ecological and behavioral methods for the study of bats, Baltimore: The Johns Hopkins University Press, p. 567-592.

WHITAKER JO JR, NEEFUS C \& KUNZ TH. 1996. Dietary variation in the Mexican free-tailed bat (Tadarida brasiliensis mexicana). J Mammal 77: 716-724.

WILLIG MR, CAMILO GR \& NOBLE SJ. 1993. Dietary overlap in frugivorous and insectivorous bats from edaphic cerrado habitats of Brazil. J Mammal 74: 117-128.
ZANON CMV \& DOS REIS NR. 2007. Bats (Mammalia, Chiroptera) in the Ponta Grossa region, Campos Gerais, Paraná, Brazil. Rev Bras Zool 24: 327-332.

\section{APPENDIX I}

Collection localities. The localities from the Yungas Forests are listed from north to south and according to its numbers in Figure 1. For each locality is provided the specific site, department and province in brackets, and coordinates and altitude in meters above sea level. In adition, species and number of individuals in brackets captured in each site are indicated.

1 - Las Capillas, $15 \mathrm{~km}$ al $\mathrm{N}$ de Las Capillas (Dr. Manuel Belgrano, Jujuy). 2402'37" S, 6507'55" W, 1061 m. Eumops glaucinus (9), Molossus molossus (1), Dasypterus ega (1), Eptesicus furinalis (1), Histiotus velatus (1), Lasiurus blossevillii (1), Lasiurus villosissimus (1).

2 - Finca Las Capillas, $3 \mathrm{~km}$ al E del cruce entre río Las Capillas y ruta provincial $n^{\circ} 20$

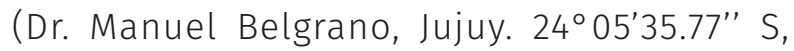
6509'07.86" W, 1141 m. Eptesicus furinalis (2), Lasiurus blossevillii (3), Lasiurus villosissimus (1).

3 - Metán, $6 \mathrm{~km}$ al O, sobre río Las Conchas (Metán, Salta). 2528'09" S, 6502'11.58" W, 986 m. Molossus molossus (3), Eptesicus furinalis (2), Lasiurus blossevillii (4).

4 - Metán, $3.5 \mathrm{~km}$ al W (Metán, Salta).

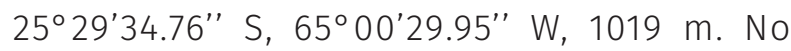
individuals of these species were captured here.

5 - Reserva Provincial Aguas Chiquitas, sobre río Aguas Chiquitas (Burruyacú, Tucumán). 2636'32.40" S, 6510'36.60" W, 605 m. Eumops bonariensis (7), Dasypterus ega (1), Eptesicus diminutus (1), Eptesicus furinalis (9), Lasiurus blossevillii (2).

6 - El Cadillal, camping La Curva (Burruyacú, Tucumán). 26³7'52.08" S, 6511'10.87" W, 555 m. 


\section{APPENDIX II}

Total samples evaluated for each species of bats and for each statistical analysis considering site characteristics, sexes, and seasons.

\begin{tabular}{|c|c|c|c|c|c|c|c|}
\hline & & \multicolumn{2}{|c|}{ Site } & \multicolumn{2}{c|}{ Sex } & \multicolumn{2}{c|}{ Season } \\
\hline Species & Total & Well-preserved & Disturbed & Male & Female & Wet & Dry \\
\hline Molossidae & & & & & & & \\
\hline Eumops bonariensis & 33 & 33 & - & 8 & 25 & 28 & 5 \\
\hline Eumops glaucinus & 79 & 79 & - & 19 & 60 & - & 79 \\
\hline Molossus molossus & 40 & 40 & - & - & 40 & - & 40 \\
\hline Vespertilionidae & & & & & & & \\
\hline Dasypterus ega & 25 & 15 & 10 & 5 & 20 & 15 & 10 \\
\hline Eptesicus diminutus & 30 & 5 & 25 & - & 30 & 24 & 6 \\
\hline Eptesicus furinalis & 121 & 75 & 46 & 32 & 89 & 84 & 37 \\
\hline Histiotus macrotus & 48 & 48 & - & - & 48 & - & 48 \\
\hline Lasiurus blossevillii & 72 & 49 & 23 & 55 & 17 & 34 & 38 \\
\hline
\end{tabular}

Promops nasutus (1), Eptesicus diminutus (6), Eptesicus furinalis (7), Lasiurus blossevillii (1).

7 - Villa de Batiruana (La Cocha, Tucumán). $27^{\circ} 38^{\prime} 11.61^{\prime \prime}$ S, 6544'40.29" W, 515 m. Dasypterus ega(1), Eptesicus furinalis (1), Lasiurus blossevillii (1).

8 - Villa de Escaba, $22 \mathrm{~km}$ al SE, sobre ruta provincial n9 (Paclín, Catamarca). 27047'48.48" S, 654' $56.70^{\prime \prime}$ W, 538 m. Eptesicus furinalis (3), Histiotus laephotis (1), Histiotus macrotus (6), Lasiurus blossevillii (3).

\section{How to cite}

GAMBOA ALURRALDE S \& DÍAZ M. 2021. Diet of arthropodophagous bats (Mammalia, Chiroptera) from Northwestern Argentina. An Acad Bras Cienc 93: e20190549. DOI 10.1590/0001-3765202120190549.

Manuscript received on May 10, 2019

accepted for publication on September 10, 2019

SANTIAGO GAMBOA ALURRALDE ${ }^{1,2}$

https://orcid.org/0000-0002-6824-8665

\section{MÓNICA DÍAZ ${ }^{1,2,3}$}

https://orcid.org/0000-0001-9519-6461

${ }^{1}$ Programa de Investigaciones de Biodiversidad Argentina (PIDBA), Programa de Conservación de los Murciélagos de Argentina (PCMA), Facultad de Ciencias Naturales e IML, Universidad Nacional de Tucumán. Miguel Lillo 205, 4000 Tucumán, Argentina

${ }^{2}$ Consejo Nacional de Investigaciones Científicas y Técnicas (CONICET), Crisóstomo Álvarez 722, 4000 Tucumán, Argentina ${ }^{3}$ Fundación Miguel Lillo, Miguel Lillo, 251, 4000 Tucumán, Argentina

Correspondence to: Santiago G. Alurralde

E-mail:santigamboaalurralde@gmail.com

\section{Author contributions}

SGA and MMD collected the specimens in the field and wrote the text; SGA analyzed the samples and drew the map.

\section{(cc) BY}

